\title{
PENGARUH HAFI GYM TERHADAP KEKUATAN OTOT PASIEN STROKE ISKEMIK
}

\author{
${ }^{1}$ Hanief Firmansyah, ${ }^{2}$ Indah Wulandari, ${ }^{3}$ Eka Ernawati \\ ${ }^{1}$ Perawat RSUD dr.Drajat Prawiranegara Serang \\ ${ }^{2,3}$ Dosen STIKes Faletehan Serang Banten \\ e-mail : alkaddihan@gmail.com
}

\begin{abstract}
Abstrak
Penelitian ini bertujuan mengetahui pengaruh Hafi Gym terhadap peningkatan kekuatan otot pasien stroke iskemik. Jenis penelitian ini adalah quasi eksperimental dengan dua kelompok. Sampel penelitian ini adalah pasien stroke yang dirawat di bangsal rawat inap sejumlah 32 orang menggunakan tehnik purposive sampling. Penelitian ini menggunakan uji $t$ independet dalam uji statistiknya. Hasil penelitian menunjukkan ada peningkatan kekuatan otot tangan dan kaki sebelum dan setelah intervensi. Kekuatan otot tangan pada kelompok intervensi meningkat dari 2,94 menjadi 4,00 sedangkan pada kelompok kontrol dari 2,63 menjadi 3,25 . Kekuatan otot kaki pada kelompok kontrol reratanya berubah dari 3,06 menjadi 3,44 sedangkan pada kelompok intervensi rerata kekuatan otot dari 3,38 menjadi 4,46. Hasil uji statistik menunjukkan ada pengaruh senam stroke terhadap peningkatan kekuatan otot tangan ( $p$ value 0,039$)$ dan terhadap kekuatan otot kaki $(p$ value 0,000$)$. Jika latihan kekuatan otot disertakan dalam terapi paska akut stroke iskemik, kekuatan otot akan meningkat secara signifikan. Karena itu perlu peran perawat dalam melakukan promosi pelaksanaan senam stroke pada pasien stroke iskemik sehingga akan mengurangi risiko deformitas atau ketergantungan akibat kelemahan paska stroke.
\end{abstract}

Kata kunci : Kekuatan otot, senam, stroke

\begin{abstract}
This study aims was determine the effect of Hafi gym to increase muscle strength on ischemic stroke patients. This research was a quasy experimental design with two groups. Samples were stroke patients, number 32 using purposive sampling technique. This study used $t$-independet test statistics. The results showed there were an improvement in hands and feet muscle strength before and after the intervention. Hand muscle strength in the intervention group increased from 2.94 to 4.00, while the control group from 2.63 to 3.25. Mean of leg muscle strength in the control group changed from 3.06 to 3.44, while the intervention group changed from 3.38 to 4.46. Statistical analysis showed there was an effect of Hafi Gym to increase hands muscle strength ( $p$ value 0.039) and leg muscles strength ( $p$ value of 0.000). If strength training is included in the post-acute treatment of ischemic stroke, it will increase significantly. It needs the nurse's role in promoting the strokegymnastics in stroke patients to reduce the risk of deformity or dependence due to weakness.
\end{abstract}

Keyword: muscle strength, gymnastic, stroke

\section{PENDAHULUAN}

Stroke merupakan penyakit vaskular di serebral yang dapat menyebabkan defisit neurologis. Stroke iskemik disebabkan oleh adanya obstruksi trombus atau ateroskleeosis di vaskular serebral yang menyebabkan terputusnya aliran darah parsial atau total pada area distal sumbatan. Penurunan aliran darah tersebut mengakibatkan menurunnya pula oksigenasi ke area distal obstruksi. Kondisi tersebut menyebabkan gangguan fokal sesuai area otak yang mengalami hipoperfusi (Mumanthaler, 2006).

Angka kecacatan utama dan kematian akibat stroke menjadi yang ketiga terbesar setelah penyakit jantung dan keganasan. 
American Heart Association and American Stroke Association (2008) mencatat terdapat lebih 5, 7 juta orang di Amerika mengalami kecacatan akibat stroke dan sebagian besar dialami oleh wanita. (American Heart Association and American Stroke Association, 2008). Riset Kesehatan dasar (2013) di Indonesia mencatat bahwa stroke termasuk 10 besar kelompok penyakit tidak menular dengan prevalensi $57,9 \%$ telah terdiagnosis oleh tenaga kesehatan. Estimasi penderita stroke di Provinsi Banten Tahun 2013 sendiri adalah 53.289 jiwa atau $6,6 \%$ dari seluruh penduduk Indonesia (Riskesdas, 2013).

Berdasarkan data dari RSUD dr. Dradjat Prawiranegara pada periode Juli Oktober 2015 diperoleh data jumlah pasien stroke non hemoragik sebanyak 365 orang sedangkan pasien stroke hemoragik sebanyak 74 orang. Sehingga dapat disimpulkan rata-rata pasien perbulan sebanyak 91 orang/bulan menderita stroke non hemoragik. (Instalasi Rawat Inap dr. Dradjat Prawiranegara, 2015).

Peningkatan prevalensi stroke di Indonesia setiap tahunnya menimbulkan pula peningkatan angka morbiditas dan mortalitas akibat stroke. Kerugian yang ditimbulkan baik saat terjadinya stroke ataupun gejala sisa paska strokeyang tidak hanya terkait pembiayaan pengobatan penyakit, tetapi juga terjadi karena berkurangnya hingga hilangnya produktivitas pasien stroke. Salah satu gejala yang sering menyertai pasien stroke dan menimbulkan penurunan produktivitas adalah hemiparase dan hemiplegi.

Hemiparese adalah kelemahan otot karena penurunan kekuatan otot (Mumenthaler, 2006). Pasien stroke seringkali mengalami hemiparese akibat lesi fokal di serebralnya. Semakin sering serangan, maka semakin berat gejala parese yang dirasakan. Pasien awalnya merasa sering kesemutan atau baal hingga tidak dapat menggerakkan tangan dan atau kakinya. Gejala ini muncul umumnya satu sisi tubuh yang sifatnya kontralateral dengan hemisfer yang mengalami lesi (Mumenthaler, 2006).

Perawatan stroke harus dilakukan secara medis dan komprehensif yang didukung dengan kemajuan teknologi, serta tindakan terapi yang tepat sangat diperlukan karena mengingat dampak lanjut dari stroke yang sangat fatal. Program. Rehabilitasi pasca stroke dapat dilakukan dengan terapi komplementer seperti relaksasi dan pemulihan kekuatan otot, salah satunya dengan senam stroke.

Tujuan dari senam stroke ini yaitu untuk memulihkan kekuatan otot, memperlancar aliran darah, mencegah anggota gerak kaku. Sebagian besar pasien stroke yang dirawat di RSUD dr. Dradjat Prawiranegara mengeluhkan sakit pada anggota gerak yang mengalami kelemahan/kelumpuhan karena tidak bergerak dalam jangka waktu yang lama. Sehingga dr. spesialis neurologi di RSU dr. Dradjat Prawiranegara selalu menganjurkan kepada pasien untuk melakukan mobilisasi agar tidak terjadi kekakuan otot.

Tujuan penelitian ini yaitu untuk mengetahui pengaruh senam stroke terhadap peningkatan kekuatan otot pada pasien stroke non hemoragik di RSU dr. Dradjat Prawiranegara Kabupaten Serang tahun 2015.

\section{METODOLOGI PENELITIAN}

Penelitian ini menggunakan desain penelitian quasy experiment design, non equivalent kontrol group. Pada rancangan ini, pengelompokan anggota sempel pada kelompok intervensi dan kelompok kontrol tidak dilakukan secara random atau acak. Penelitian dilakukan di RSUD dr. Drajat Prawiranegara Serang dengan sampel pasien stroke iskemik sejumlah 16 orang pada kelompok kontrol dan 16 orang pada kelompok intervensi. Pengambilan sampel menggunakan tehnik purposive sampel. Ditentukan bahwa kriteria inklusi penelitian adalah pasien stroke iskemik yang tidak mengalami penurunan kesadaran atau kondisi kritis. 
Senam stroke yang digunakan adalah modifikasi dari gerakan ROM dan gerakan senam yang sudah ada. Peneliti mendiskusikan terlebih dahulu gerakan yang dijadikan gerakan senam kemudian memberikan identitas gerakan-gerakan tersebut sebagai Hafi Gym. Intervensi senam stroke tersebut dilakukan segera setelah fase akut stroke dilewati, yaitu pada hari kedua atau ketiga hingga lima hari berikutnya secara teratur, dengan frekuensi senam 5-6 kali/hari. Dilakukan penilaian kekuatan otot pada saat sebelum intervensi dan pengukuran kedua pada hari keenam paska intervensi. Pada kelompok intervensi juga dilakukan pengukuran pada hari kedua atau ketiga hingga lima hari berikutnya. Intervensi Hafi Gym dilakukan bersamaan terapi medis sesuai prosedur tetap dari dokter.

Analisa data yang digunakan untuk melihat pengaruh intervensi Hafi Gym terhadap kekuatan otot adalah uji tindependen dengan melihat selisih kekuatan otot sebelum dan setelah intervensi pada kelompok kontrol dan kelompok intervensi.

\section{HASIL PENELITIAN}

Hasil penelitian menunjukkan adanya signifikansi peningkatan kekuatan otot lengan dan otot kaki antara kelompok intervensi dengan kelompok kontrol. Pada kelompok kontrol rerata kekuatan otot tangan hanya meningkat 0,62 poin dari 2,63 pada hari ke-2 serangan menjadi 3,25 hari ke-5 serangan. Sedangkan pada kelompok intervensi kekuatan otot meningkat 1,06 poin dari 2,94.

Tabel 1. Peningkatan kekuatan otot sebelum dan setelah intervensi pada kelompok kontrol dan kelompok intervensi

\begin{tabular}{clccc}
\hline No & $\begin{array}{c}\text { Kekuatan } \\
\text { Otot }\end{array}$ & Sebelum & Setelah & $\begin{array}{c}p- \\
\text { value }\end{array}$ \\
\hline 1. & Tangan & & & \\
\cline { 2 - 4 } & Kontrol & 2,63 & 3,25 & \multirow{2}{*}{0,039} \\
\cline { 2 - 4 } & Intervensi & 2,94 & 4,00 & \\
\hline 2. & Kaki & & & \\
\cline { 2 - 4 } & Kontrol & 3,06 & 3,44 & 0 \\
\cline { 2 - 4 } & Intervensi & 3,38 & 4,56 & \\
\hline
\end{tabular}

Peningkatan kekuatan otot secara signifikan juga dapat dilihat pada peningkatan kekuatan otot kaki. Pada kelompok kontrol kekuatan otot meningkat dari 3,06 menjadi 3,44 (1,06 poin) sedangkan peningkatan yang cukup besar didapatkan pada kelompok intervensi yaitu dari 3,38 menjadi 4,56 (1,18 poin).

Hasil uji statistik menujukkan $p$-value 0,039 pada variabel kekuatan otot lengan dan 0,000 pada variabel kekuatan otot kaki. Nilai tersebut menunjukkan adanya signifikansi intervensi terhadap peningkatan kekuatan otot.

Diagram 1. Peningkatan kekuatan otot sebelum dan setelah intervensi pada kelompok kontrol dan kelompok intervensi.

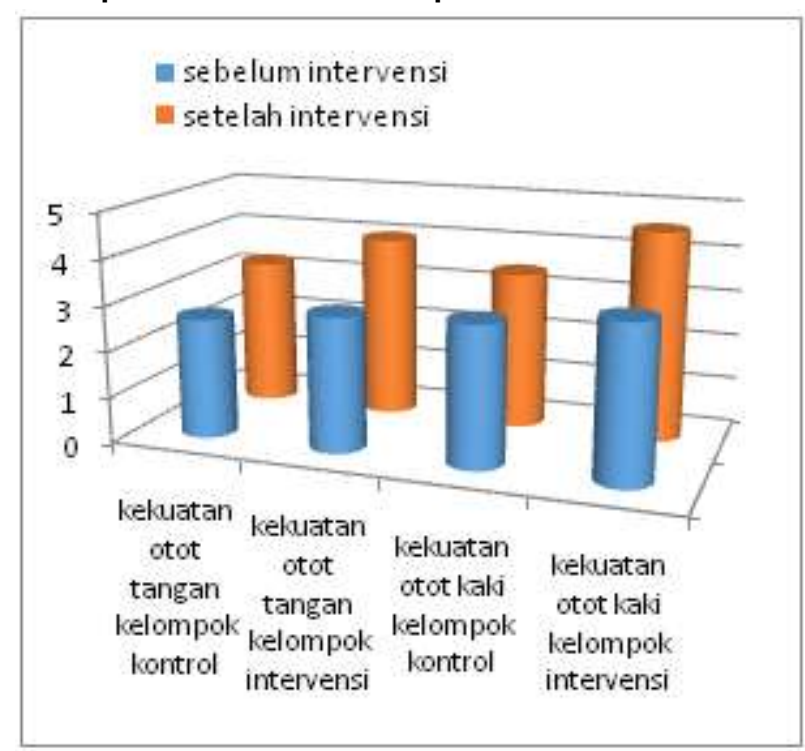

Jika ditinjau hasil penelitian yang didapatkan, maka terlihat peningkatan kekuatan otot yang signifikan pada kelompok intervensi sebelum dan setelah intervensi. Peningkatan tersebut dapat dilihat pada diagram 1.1. Walau terlihat pada diagram ada peningkatan kekuatan otot tangan dan kaki pada kelompok kontrol, namun pada kelompok intervensi peningkatan terlihat lebih tinggi.

\section{PEMBAHASAN}

Stroke iskemik terjadi umumnya disebabkan oleh produksi trombus lokal pada arteri serebral atau berasal dari 
material emboli yang berasal dari jantung, seringkali ateroma berasal dari arteri di leher yang merupakan bagian distal aorta (Wilkinson, 1999). Oklusi pada arterial serebral tersebut dapat menimbulkan iskemia tiba-tiba pada jaringan otak yang mendapatkan sirkulasi dari arteri tersebut. Manifestasi yang muncul berkaitan erat dengan fungsi dari setiap area otak. Hemiparese terjadi sebagai salah satu manifestasi hilangnya fungsi jaringan otak akibat iskemia.

Otak menerima darah melalui dua arteri utama yaitu arteri karotis interna dan arteri vertebralis. Arteri karotis interna akan bercabang menjadi arteri serebral anterior (anterior cerebral artery/ ACA) dan middle cerebral artery (MCA) yang berfungsi memerdarahi area anterior dan area tengah serebral. Penurunan sirkulasi ke area anterior otak menimbulkan gejala defisit motorik. Studi literatur menunjukkan stroke iskemik sebagian besar terjadi pada arteri serebral bagian anterior dan MCA. Hal ini menimbulkan sebagian besar manifestasi klinis yang ditemukan adalah penurunan fungsi motorik kontralateral di wajah dan lengan (oklusi di MCA) dankelemahan di kontralateral kaki (oklusi di ACA) (Wilkinson, 1999; Purves, Agustine, Fitzpatrick, 2001).

Gangguan fungsi motorik pada pasien stroke iskemik dapat diatasi melalui manajemen yang tepat. Pemulihan setelah defisit neurologis dapat dicapai melalui mobilisasi dini, memertahankan tekanan darah, fisioterapi, serta terapi okupasional (Wilkinson, 1999). Latihan kontinyu dalam manajemen fisioterapi paska stroke berfungsi meningkatkan mobilitas, memulihkan kontrol motorik, mencegah kontraktur dan paralisis ekstremitas, mencegah penurunan fungsi neuromuskular, dan memperbaiki sirkulasi (Brunner and Suddarth, 2005). Selain itu latihan teratur membantu mencegah statis vena yang dapat menyebabkan terbentuknya trombosis dan emboli pulmonal (Brunner and Suddarth, 2005).

Aktivitas fisik atau latihan seperti senam yang teratur membentuk pula jalur (pathway) baru di sistem saraf pusat menggantikan sel saraf yang sudah rusak akibat hipoperfusi. Latihan teratur juga dapat memperkuat pola baru yang telah dibentuk tadi. Awalnya ekstremitas mungkin terasa kaku namun akan berangsur membaik. Jika area lesi luas dan banyak area otot yang mengalami kekakuan, maka latihan perlu dilakukan lebihn sering. Umumnya latihan dilakukan 4-5 kali/ hari (Brunner and Suddarth, 2005). Bergerak merupakan penatalaksanaan yang diperlukan selain pengobatan secara medis. Bergerak memicu terbentuknya sirkuit yang akan terbentuk bila ada "kebutuhan" akan gerak tersebut. Bila ekstremitas yang sakit tidak pernah digerakkan sama sekali, presentasinya di otak akan mengecil dan terlupakan

Hafi Gym adalah jenis senam stroke yang dibuat berdasarkan kreativitas dari perawat pelaksana RSUD dr. Drajat Prawiranegara Serang bersama tim pengajar Keperawatan Medikal Bedah STIKes Faletehan Serang. Gerakan dalam senam ini pada dasarnya merupakan modifikasi dari gerakan dasar range of motion (ROM). Hafi gym ini diharapkan dapat membantu meningkatkan kekuatan otot pada pasien stroke akibat hemiparese, meningkatkan kemandirian ADL dan akhirnya meningkatkan kualitas hidup pasien.

Hafi gym disusun sebagai metode latihan untuk dapat memberikan rangsangan pada reseptor yang dibawa ke otak untuk diproses dan menghasilkan haluaran berupa gerakan yang terkoordinasi. Metode latihan yang mendasari gerakan senam stroke diantaranya adalah latihan perkembangan persyarafan, latihan pada kedua sisi dan reflek simetris asimetris. Seperti halnya gerakan senam pada umumnya, gerakan senam stroke juga terbagi 3 bagian, gerakan-gerakan ini dilakukan sebanyak 4-6x perhari.

Hasil penelitian menunjukkan terjadi peningkatan kekuatan otot tangan maupun kaki setelah dilakukan Hafi Gym pada pasien stroke non hemoragik. Hasil 
penelitian ini sejalan dengan penelitian yang dilakukan Basmara (2011) di RSUP M. Djamil Padang bahwa senam stroke berpengaruh terhadap perbaikan kemampuan fungsional pasien pasca stroke. Gerakan pada Hafi Gym dilakukan saat pasien berbaring, duduk, dan berdiri. Setiap gerakan mempunyai tujuan sendiri dan tergantung kemampuan pasien melakukannya. Gerakan meliputi gerakan pada kepala, tangan, dan kaki. gerakan ini kemudian dilakukan pasien sebagai latihan senam stroke yang dapat dilanjutkan hingga pasien berada di rumah.

Latihan seperti senam stroke dapat meningkatkan respon adaptasi muskuloskeletal terhadap stimulasi yang diberikan. Adaptasi selular setalah latihan dapat meningkatkan kemampuan rata-rata sintesis pada komponen selular. Jika ratarata sintesis melebihi rata-rata degradasi, maka terjadi peningkatan komponen selular. Perubahan pada sintesis protein memerlukan signal selular, salah satunya adalah faktor biologis dan fisiologis yang melanjutkan proses komunikasi pada otot yang berbeda, menyebabkan perubahan selular sehingga akan terjadi peningkatan kekuatan otot (Sherwood, 2001).

Selama gerakan senam stroke bagian kaki berlangsung, peneliti menemukan hambatan diantara pada responden yang memiliki tubuh obesitas responden merasa kesulitan untuk melakukan gerakan tersebut, dan gerakan kemudian dibantu oleh peneliti, pada responden lainnya merasakan nyeri untuk melakukan gerakangerakan senam yang diinstruksikan peneliti. Nyeri sering terjadi setelah stroke dan sangat mengganggu terapi latihan. Nyeri dapat merupakan akibat atau komplikasi dari stroke. Lesi yang mengenai area talamus seringkali menimbulkan nyeri yang disebut sebagai thalamic pain syndrome. Nyeri jenis itu disebabkan oleh gangguan sensorik sentral dimana interpretasi stimulus yang datang dari luar diterima sebagai rasa nyeri di otak. Sayangnya nyeri tersebut tidak selalu mudah diatasi, namun dapat dicoba dengan pemberian trisiklik antidepresan atau antikonvulsan (Misbach, 2011).

Senam stroke akan mengubah energi kimia ATP menjadi energi mekanis. Gerakan senam akan menyebabkan terjadinya kontraksi otot. Kontraksi diawali dengan adanya asetilkolin yang dikeluarkan dari ujung terminal neoron motorik sehingga akan mengakibatkan potensial aksi di sel otot yang akan merambat keseluruh permukaan membran. Selanjutnya aktivitas listrik permukaan sel otot dibawa ke sentral serat otot oleh tubulus $\mathrm{T}$.

Adanya penyebaran potensial aksi ke tubulut $\mathrm{T}$ mencetuskan pelepasan simpanan $\mathrm{Ca}^{++}$dari kantung-kantung lateral reticulum sarkoplasma didekat tubulus. $\mathrm{Ca}^{++}$yang dilepaskan berikatan dengan troponin dan mengubah bentuknya, sehingga kompleks troponin-tropomiosin secara fisik tergeser ke samping, membuka tempat pengikatan jembatan silang aktin. Bagian aktin yang telah terbuka kemudian berikatan dengan jembatan silang myosin, yang sebelumnya telah mendapat nenergi dari penguraian ATP menjadi ADP + $P_{i}+$ energi oleh ATPase miosin di jembatan silang.

Pengikatan aktin dan miosin di jembatan silang menyebabkan jembatan silang menekuk (kontraksi), kontraksi yaitu hasil suatu gerakan mengayun kuat yang menarik filamen tipis ke arah dalam. Pergeseran ke arah dalam dari semua filamen tipis yang mengelilingi filamen tebal memperpendek sarkomer (Sherwood, 2001). Selama kontraksi berlangsung gerakan mengayun terjadi sangat kuat, sehingga akan membebaskan ADP dan $\mathrm{P}_{\mathrm{i}}$ dari jembatan silang. Perlekatan sebuah molekul ATP baru memungkinkan terlepasnya jembatan silang, yang mengembalikan bentuknya ke bentuk semula. Penguraian molekul ATP yang baru oleh ATPase miosin kembali memberikan energy bagi jembatan silang. Apabila $\mathrm{Ca}^{++}$ masih ada akan mengakibatkan kompleks troponin-troponinmiosin tetap tergeser kesamping, jembatan silang kembali menjalani siklus pengikatan dan penekukan, 
menarik filament tipis selanjutnya (Sherwood, 2001).

Apabila tidak terdapat lagi potensial aksi lokal akan terjadi relaksasi, yaitu $\mathrm{Ca}^{++}$ secara aktif telah kembali ke tempat penyimpanannya di kantung lateral reticulum sarkoplasma, kompleks troponintroponinmiosin bergeser kembali ke posisinya menutupi tempat pengikatan jembatan silang aktin, sehingga aktin dan miosin tidak lagi berikatan di jembatan silang, dan filamen tipis bergeser kembali ke posisi istirahat (Sherwood, 2001).

Terapi latihan gerak yang diberikan adalah gerak fungsional (senam stroke) daripada gerak tanpa ada tujuan tertentu. Gerak fungsional misalnya gerakan menggenggam. Gerak fungsional mengikutsertakan dan mengaktifkan bagianbagian dari otak, baik area lesi maupun area otak normal lainnya, menstimulasi sirkuit baru yang dibutuhkan. Melatih gerak seperti menekuk dan meluruskan (fleksi- ekstensi) siku lengan yang lemah menstimulasi area lesi saja. Apabila akhirnya lengan tersebut bergerak, tidak begitu saja bisa digunakan untuk gerak fungsional, namun tetap memerlukan terapi latihan agar terbentuk sirkuit yang baru.

Selama latihan pasien diarahkan untuk melakukan gerak fungsional yang normal, jangan biarkan menggunakan gerak abnormal. Gerak normal artinya sama dengan gerak pada sisi sehat. Bila sisi yang terkena masih terlalu lemah, berikan bantuan tenaga secukupnya dimana pasien masih menggunakan ototnya secara aktif. Bantuan yang berlebihan membuat pasien tidak menggunakan otot yang akan dilatih (otot bergerak pasif). Bantuan tenaga yang kurang menyebabkan pasien mengerahkan tenaga secara berlebihan dan mengikutsertakan otot-otot lain. Ini akan memperkuat gerakan ikutan ataupun pola sinergis yang memang sudah ada dan seharusnya dihindari. Besarnya bantuan tenaga yang diberikan harus disesuaikan dengan kemajuan pemulihan pasien.

Gerakan fungsional dalam Hafi Gym dapat dilatih apabila stabilitas batang tubuh sudah tercapai, yaitu dalam posisi duduk dan berdiri. Stabilitas duduk dibedakan dalam stabilitas duduk statik dan dinamik. Stabilitas duduk statik tercapai apabila pasien telah mampu mempertahankan duduk tegak tidak bersandar tanpa berpegangan dalam kurun waktu tertentu tanpa jatuhm miring ke salah satu sisi. Stabilitas duduk dinamik tercapai apabila pasien dapat mempertahankan posisi duduk sementara batang tubuh (kepala dan bahu) dapat digerakkan ke arah depan dan belakang. Hasil latihan ini memungkinkan pasien mampu melakukan aktivitas dalam posisi berdiri. Kemampuan fungsional optimal dicapai apabila pasien juga mampu melakukan aktivitas sambil berjalan.

Saat akan senam stroke persiapkan pasien dalam kondisi stabil. Gerak fungsional yang dilatih akan memberikan hasil maksimal apabila pasien siap secara fisik dan mental. Secara fisik harus diperhatikan kelenturan otot-otot, lingkup gerak semua persendian tidak ada yang terbatas, dan tidak ada nyeri pada pergerakan. Secara mental pasien mempunyai motivasi dan pemahaman akan tujuan dan hasil yang akan dicapai dengan terapi latihan senam stroke tersebut. Kondisi medis juga menjadi salah satu pertimbangan. Tekanan darah dan denyut nadi sebelum dan sesudah latihan perlu dimonitor. Lama latihan tergantung pada stamina pasien. Terapi latihan yang sebaiknya adalah latihan yang tidak sangat melelahkan, durasi tidak terlalu lama (umumnya sekitar 30 menit) namun dengan pengulangan sesering mungkin.

Intervensi senam stroke ditujukan untuk mencegah timbulnya komplikasi akibat tirah baring, menyiapkan atau mempertahankan kondisi yang memungkinkan pemulihan fungsional yang paling optimal, mengembalikan kemandirian dalam melakukan aktivitas sehari-hari, mengembalikan kebugaran fisik dan mental. Pemulihan fungsional mempunyai "periode emas" yang terbatas waktunya; stimulasi yang diberikan pada 3 bulan pertama akan lebih memberikan hasil dibandingkan fase 
kronis, dan tentu tidak boleh disia-siakan. Pasien harus diberikan motivasi untuk selalu aktif melakukan aktivitas sesuai dengan kemampuan yang ada dan juga latihan senam stroke.

\section{KESIMPULAN}

Kesimpulan penelitian ini adalah bahwa latihan teratur seperti senam stroke pada pasien stroke iskemik dapat meningkatkan kekuatan otot. Terjadi peningkatan kekuatan otot secara signifikan setelah dilakukan senam stroke. Latihan menjadi lebih bermakna jika dilakukan sedini mungkin setelah kondisi akut pasien tidak ada lagi.

\section{SARAN}

Saran dalam penelitian ini adalah sebaiknya perawat ikut berperan serta aktif dalam memberikan intervensi keperawatan mandiri dan motivasi kepada pasien stroke untuk melakukan latihan secara teratur. Pasien tidak lagi hanya mengandalkan fisioterapis untuk memperbaiki dan meningkatkan kekuatan otot namun dapat secara mandiri melakukan latihannya di rumah. Diperlukan peran perawat sebagai edukator untuk memfasilitasi pasien mencapai tujuan asuhan keperawatannya secara mandiri.

\section{Daftar Pustaka}

Balitbangkes Kemenkes RI., (2013). RISKESDAS. Diakses melalui http://www.depkes.go.id

Brunner and Suddarth, (2005). Medical Surgical Nursing. E-Book. Philadelphia: Lippincott William and Wilkins. , (2010). Text Book of Medical Surgical Nursing. E-Book. 12th Ed. Philadelphia: Lippincott William and Wilkins.

Hickey, J.V., (2013). The Chinical Practice of Neurological and Neurosurgical Nursing. Houston: Lippincott Williams \& Wilkins.

Johnstone, M., (1995). Restoration of Normal Movement after Stroke. Edinburg: Churchill Livingstone.
Lindsay KW, Bone I. 2004. Neurology and Neurosurgery Illustrated. 4th Edition. Philadelphia: Elsevier Limited

Manji, Hi,. (1998). The Ultimate PocketSized Guideto Neurology. Uk: Oxford Handbook Of Neurology.

Mumenthaler M, and Mattle H., 2006. Fundamentals of Neurology: An Illustrated Guide. New Yuk: Thieme Stuttgart.

Purves, D, Agustine GJ, Fitzpatrick D, et. al., (2001). Neuroscience.The blood supply of the brain and spinal cord. 2nd Edition. Diakses melalui http://www.ncbi.nlm. nih.gov

Wilkinson, I.M.S., (1999). Essential Neurology. 3rd Edition. London: Blackwell Science Ltd. 